\title{
IMPLEMENTASI PEMBELAJARAN ABAD 21 DALAM KURIKULUM 2013
}

\author{
Yusuf Andrian dan Rusman \\ Universitas Pendidikan Indonesia \\ e-mail: yusuf.andrian@student.upi.edu
}

\begin{abstract}
Abstrak
Penelitian ini merupakan penelitian deskripsi yang dilakukan pada 39 SMA Rujukan yang ada di Provinsi DKI Jakarta. Penelitian ini bertujuan untuk mendeskripsikan implementasi pembelajaran abad 21 dalam Kurikulum 2013 pada mata pelajaran Fisika di SMA Rujukan Provinsi DKI Jakarta. Fokus penelitian diarahkan pada empat sub variabel yaitu; 1) perencanaan pembelajaran; 2) pelaksanaan pembelajaran; 3) penilaian pembelajaran; dan 4) pengawasan pembelajaran. Responden yang dilibatkan dalam penelitian adalah guru mata pelajaran Fisika. Pada penelitian ini digunakan angket untuk mengumpulkan data dan menggunakan skala Likert dengan skor 1 sampai 4. Selanjutnya, data tersebut diolah dengan menggunakan teknis analisis deskriptif persentase. Perencanaan pembelajaran abad 21 dalam kurikulum 2013 termasuk dalam kategori baik dengan rentang nilai antara 23-27. Sedangkan pelaksanaan pembelajaran juga pada kategori baik dengan rentang nilai antara 46-55. Adapun penilaian pembelajaran dalam kategori baik dengan rentang nilai antara 29-34. Dan pengawasan pembelajaran berada pada kategori baik dengan rentang nilai 23-27. Hasil penelitian diharapkan dapat menjadi masukan bagi Kementerian Pendidikan dan Kebudayaan, khususnya bagi Direktorat Pembinaan SMA, mengenai kondisi riil di lapangan berkaitan dengan implementasi Kurikulum 2013 SMA sehingga dapat dijadikan bahan pertimbangan dalam pengambilan kebijakan selanjutnya.
\end{abstract}

Kata Kunci: pembelajaran abad 21, kurikulum 2013, Fisika, SMA Rujukan

\section{IMPLEMENTATION OF 21 ${ }^{\text {st }}$ CENTURY LEARNING IN CURRICULUM 2013}

\begin{abstract}
This research is a description research conducted from 39 SMA Rujukan in Province of DKI Jakarta. This study aims to describe the implementation of $21^{\text {st }}$ century learning in Curriculum 2013 in the subject matter of physics at SMA Rujukan in Province of DKI Jakarta. The focus research is directed to four sub variables namely; (1) planning of learning; (2) implementing of learning; (3) assessment of learning; \& (4) monitoring of learning. Respondents in this research are teacher of Physics subject. This study used questionnaires to collect data and use Likert scale with a score of 1 to 4. Furthermore, the data is processed by using technical analysis descriptive percentage. 1st century learning planning in the 2013 curriculum is included in the good category with a range of values 23-27. While the implementation of learning is also in the good category with a range of values 46-55. While learning assessment is in a good category with a range of values 29-34. And supervision of learning is placed in a good category with a range of values 23-27. The results of this study are expected to be an input or recommendation for the Ministry of Education and Culture, especially for the Directorate of High School Development, regarding with the real conditions in the school related to the implementation of Curriculum 2013 so it can be taken into consideration for the next policy making.
\end{abstract}

Keywords: $21^{\text {st }}$ century learning, curriculum 2013, physics, SMA Rujukan 


\section{PENDAHULUAN}

Pendidikan saat ini diharapkan dapat menghasilkan SDM yang memiliki kemampuan komunikasi dan kolaborasi yang kuat, ahli dalam menggunakan teknologi, keterampilan berpikir kreatif dan inovatif serta kemampuan untuk memecahkan masalah (Miller \& Northern, 2011). Senada dengan pendapat tersebut, Murti (2015) mengungkapkan bahwa di abad ke 21 ini, pendidikan menjadi semakin penting untuk menjamin peserta didik memiliki keterampilan belajar dan berinovasi, keterampilan menggunakan teknologi dan media informasi, serta dapat bekerja, dan bertahan dengan menggunakan keterampilan untuk hidup (life skills). Berbagai kompetensi yang dibutuhkan oleh peserta didik di era globalisasi saat ini sering disebut juga dengan keterampilan abad 21 $\left(21^{\text {st }}\right.$ Century Skills) dan konsep pendidikannya lebih dikenal dengan istilah pembelajaran abad 21 (21 ${ }^{\text {st }}$ Century Learning).

Pada dasarnya, kompetensi abad 21 ini sudah diadaptasi dalam sistem pendidikan di Indonesia melalui Kurikulum 2013. Bahkan tidak hanya konsep mengenai keterampilan abad 21 saja, namun Kurikulum 2013 juga mengadopsi dua konsep utama lainnya yaitu pendekatan saintifik dan penilaian autentik (Murti, 2015; Wahyudin, Rusman \& Rahmawati, 2017; Kamiludin \& Suryaman, 2017). Pendekatan saintifik di-gunakan untuk membiasakan peserta didik dengan cara berpikir ilmuwan dan pembelajarannya dilakukan dengan prosedur $5 \mathrm{M}$ yaitu: mengamati, menanya, mengeksplorasi/mengumpulkan data, mengasosiasi dan mengkomunikasikan (Sufairoh, 2016; Clorawati, Rohiyat dan Amir, 2017).

Adapun penilaian dengan pendekatan otentik dimaksudkan untuk dapat mengukur secara signifikan hasil belajar peserta didik pada aspek sikap, keterampilan, dan pengetahuan (Kemendikbud, 2013). Signifikan yang dimaksud dalam konteks ini adalah penilaian dilakukan secara komprehensif, sehingga diperoleh informasi yang lengkap mengenai kemajuan belajar peserta didik. Dengan demikian, dapat disimpulkan bahwa Kurikulum 2013 merupakan penyempurnaan dari kurikulum yang berlaku sebelumnya (KTSP 2006) dan menekankan pada pendidikan karakter serta penguasaan kompetensi yang utuh dari aspek sikap, pengetahuan, dan keterampilan (Nursamsu \& Baihaqi, 2016).

Meskipun sudah sekitar empat tahun berjalan, namun implementasi Kurikulum 2013 di lapangan masih belum optimal. Beberapa hasil penelitian menunjukkan bahwa pembelajaran di kelas yang dilakukan oleh guru masih mencirikan pembelajaran konvensional. Parasamya dan Wahyuni (2017) menyampaikan hasil studi pendahuluannya di salah satu SMA Negeri di Provinsi Aceh bahwa masih ada guru yang menggunakan pendekatan konvensional, dimana siswa hanya memperoleh pengetahuan yang disampai-kan oleh guru. Kondisi tersebut menyebabkan hasil belajar siswa yang didapatkan tidak sesuai dengan yang diharapkan.

Senada dengan Istyowati, A., dkk. (2017) yang melakukan studi di lima SMA Negeri di Kota Malang-Jawa Timur, mengungkapkan bahwa pembelajaran Fisika saat ini masih belum dapat membuat siswa untuk aktif dan terlibat langsung dalam kegiatan pembelajaran. Selanjutnya, Fitriyah dan Arif (2017) mengungkapkan pelaksanaan pembelajaran Fisika di salah satu MAN Mojosari Mojokerto masih sering menggunakan metode ceramah dan tidak melibatkan peserta didik sehingga mereka menjadi kurang aktif dan kreatif.

Lestari, dkk. (2013) mengemukakan pembelajaran saat ini cenderung memberikan porsi guru aktif-siswa pasif, guru memberi-siswa menerima, dan guru menjelaskan-siswa mendengarkan, sehingga siswa belum mampu mengaktualkan kemampuan yang dimilikinya. Mendukung beberapa pendapat tersebut, Sudarsana (2018) mengatakan bahwa meskipun Kurikulum 2013 sudah diberlakukan, namun pelaksanaan pembelajarannya di kelas masih tampak seperti pelaksanaan pembelajaran dalam Kurikulum 2006 (KTSP). 
Melihat kondisi nyata di lapangan yang tidak sesuai dengan kondisi ideal yang diharapkan, maka sangat diperlukan untuk dilakukan penelitian lebih lanjut terkait implementasi Kurikulum 2013 dan difokuskan pada proses pembelajaran. Penelitian terkait dengan implementasi Kurikulum 2013 telah banyak dilakukan oleh para peneliti terdahulu. Salah satunya yaitu penelitian yang dilakukan oleh Clorawati, Rohiyat dan Amir (2017). Penelitian mereka bertujuan untuk mendeskripsikan implementasi Kurikulum 2013 bagi guru Kimia di SMA Negeri Kota Bengkulu. Fokus penelitian ditujukan pada perencanaan, pelaksanaan, dan penilaian pembelajaran. Hasil penelitiannya secara umum menyimpulkan bahwa para guru Kimia di 10 SMA Negeri se Kota Bengkulu pada tahun ajaran 2016/2017 telah melaksanakan Kurikulum 2013 dengan kategori sebagian besar terlaksana.

Susilana dan Rusman (2015) juga mengkaji implementasi Kurikulum 2013 namun pada jenjang sekolah dasar (SD). Tujuan penelitiannya yaitu mengungkap permasalahan yang berkenaan dengan respon guru SD terhadap implementasi Kurikulum 2013 di Kota Bandung dilihat dari kegiatan perencanaan, pelaksanaan, dan penilaian kurikulum dan best practice yang dapat dicontoh dalam hal perencanaan, pelaksanaan, dan penilaian kurikulum yang dilakukan oleh guru SD di Kota Bandung. Hasil penelitian menunjuk-kan bahwa respon guru SD terhadap terhadap implementasi Kurikulum 2013 di Kota Bandung berada pada kategori positif. Terdapat beberapa "best practice" yang dapat dicontoh dalam perencanaan, pelaksanaan, dan penilaian dari guru SD di Kota Bandung terkait dengan implementasi Kurikulum 2013 berupa kegiatan "sharing", "hearing", "in house training", dan "modelling real teaching" yang dilaksanakan di KKG atau KKG gugus.

Berbagai penelitian terdahulu yang disebutkan di atas telah berhasil memberikan informasi terkait perencanaan, pelaksanaan, dan penilaian pembelajaran dalam Kurikulum 2013. Namun dari beberapa penelitian tersebut belum ditujukan untuk mengungkapkan bagaimana implementasi pembelajaran abad 21 dalam Kurikulum 2013, khususnya pada mata pelajaran Fisika di SMA Rujukan. Oleh karena itu, penting dilakukan penelitian lanjutan untuk memperoleh informasi tersebut. Berdasarkan latar belakang masalah ini penulis tertarik untuk melakukan penelitian dengan judul "Implementasi Pembelajaran Abad 21 dalam Kurikulum 2013 pada Mata Pelajaran Fisika di SMA Rujukan Provinsi DKI Jakarta”.

\section{METODE}

Metode yang digunakan dalam penelitian ini adalah metode kuantitatif. Metode penelitian kuantitatif merupakan salah satu jenis penelitian yang spesifikasinya adalah sistematis, terencana dan terstruktur dengan jelas sejak awal hingga pembuatan desain penelitiannya (Sugiyono, 2013). Metode kuantitatif dipilih dalam penelitian ini karena peneliti ingin memperoleh informasi yang akurat terkait dengan implementasi pembelajaran Abad 21 dalam Kurikulum 2013 pada mata pelajaran Fisika di SMA Rujukan Provinsi DKI Jakarta.

Pendekatan deskriptif digunakan dalam mengumpulkan data dan mengungkapkan rumusan masalah. Pendekatan deskriptif berfungsi untuk mendeskripsikan atau memberi gambaran terhadap objek yang diteliti melalui data atau sampel yang telah terkumpul sebagaimana adanya (Sugiyono, 2013). Penelitian kuantitatif deskriptif dilakukan dengan cara mencari informasi tentang gejala yang ada, didefinisikan dengan jelas tujuan yang akan dicapai, merencanakan cara pendekatannya, mengumpulkan data sebagai bahan untuk membuat laporan. Jenis penelitian deskriptif kuantitatif dinilai sesuai dengan tujuan penelitian yang hendak dicapai yaitu untuk memperoleh deskripsi tentang implemen-tasi Pembelajaran Abad 21 dalam Kurikulum 2013 pada mata pelajaran Fisika di SMA Rujukan Provinsi DKI Jakarta.

Populasi dalam penelitian ini yaitu seluruh SMA Rujukan yang ada di provinsi 
DKI Jakarta tahun 2018 sebanyak 39 sekolah. Adapun, sampel yang diambil dalam penelitian ini menggunakan teknik sampling jenuh atau dengan kata lain populasi penelitian digunakan sebagai sampel penelitian. Dengan demikian, sampel dalam penelitian ini adalah 39 SMA Rujukan di provinsi DKI Jakarta tahun 2018. Responden yang dipilih sebagai sumber data yaitu guru mata pelajaran Fisika. Adapun sebaran responden penelitian disajikan dalam Tabel 1 berikut.

Tabel 1. Sebaran Responden Penelitian

\begin{tabular}{clc}
\hline No & \multicolumn{1}{c}{ Kab./Kota } & $\begin{array}{c}\text { Jumlah } \\
\text { Responden }\end{array}$ \\
\hline 1 & Kabupaten Kep. & 1 \\
& Seribu & 3 \\
2 & Kota Jakarta Pusat & 6 \\
3 & Kota Jakarta Barat & 12 \\
4 & Kota Jakarta & 11 \\
& Selatan & 6 \\
5 & Kota Jakarta Timur & 39 \\
6 & Kotan Jakarta Utara & Total \\
\hline
\end{tabular}

Instrumen penelitian yang dipergunakan dalam penelitian ini berupa kuisioner yang dibuat sendiri oleh peneliti.

Sedangkan, untuk memudahkan dalam melakukan analisis data yang telah diperoleh dari responden, data tersebut ditabulasikan sesuai dengan jawaban responden pada kuesioner ke dalam tabel, kemudian dihitung persentasenya, dan selanjutnya dianalisis.

\section{HASIL DAN PEMBAHASAN Hasil}

Variabel yang diteliti dalam penelitian ini pada dasarnya merupakan judul penelitian yaitu Implementasi Pembe-lajaran Abad 21 dalam Kurikulum 2013 pada Mata Pelajaran Fisika di SMA Rujukan Provinsi DKI Jakarta (X). Selanjutnya, penelitian ini difokuskan pada empat sub variabel berdasarkan standar proses pembelajaran antara lain; perenca-naan pembelajaran $\left(\mathrm{X}_{1}\right)$; pelaksanaan pembelajaran $\left(\mathrm{X}_{2}\right)$; penilaian pembelajaran $\left(\mathrm{X}_{3}\right)$; dan pengawasan pembelajaran $\left(\mathrm{X}_{4}\right)$.
Pernyataan yang digunakan untuk mengukur variabel penelitian sebanyak empat puluh dua (42) pernyataan. Jawaban setiap pernyataan menggunakan skala Likert dengan gradasi nilai sangat positif (4) sampai sangat negatif (1). Jawaban tersebut berupa kata-kata Sangat Sesuai, Sesuai, Kurang Sesuai, dan Sangat Tidak Sesuai. Secara umum, data deskriptif masingmasing sub variabel dirangkum dalam Tabel 2 di bawah ini.

Tabel 2. Data Deskriptif Masing-masing Sub Variabel

\begin{tabular}{lcccc}
\hline \multicolumn{1}{c}{ Deskripsi } & $\mathrm{X}_{1}$ & $\mathrm{X}_{2}$ & $\mathrm{X}_{3}$ & $\mathrm{X}_{4}$ \\
\hline Rata-rata & 22,58 & 46,05 & 28,37 & 23,29 \\
Median & 23,00 & 48,50 & 29,00 & 24,00 \\
Modus & 22,23, & & 29 dan & \\
& 25 dan & 49 & 32 & 25 \\
& 26 & & & \\
Std. Deviasi & 4,378 & 7,935 & 5,248 & 4,849 \\
Min & 13 & 25 & 16 & 10 \\
Maks & 31 & 62 & 37 & 32 \\
\hline
\end{tabular}

Adapun penyajian berdasarkan masing-masing sub variabel dapat dilihat pada pembahasan berikut. Mulai dari sub variabel perencanaan pembelajaran $\left(X_{1}\right)$, pelaksanaan pembelajaran $\left(\mathrm{X}_{2}\right)$, penilaian pembelajaran $\left(\mathrm{X}_{3}\right)$, hingga pengawasan pembelajaran $\left(\mathrm{X}_{4}\right)$.

1. Sub Variabel Perencanaan

Pembelajaran

Rentang teoritik skor pada sub variabel perancanaan pembelajaran yaitu 8 untuk skor terendah dan 32 untuk skor tertinggi. Adapun berdasarkan hasil pengumpulan data, statistik deskriptif data sub variabel perencanaan pembelajaran menunjukkan skor terendah yaitu 13 dan skor tertinggi yaitu 31. Berdasarkan hasil perhitungan diperoleh skor rata-rata pada sub variabel perencanaan pembelajaran yaitu 22,58. Median terletak pada skor 23 dan modusnya terlihat pada skor 22, 23, 25 dan 26. Sementara itu, standar deviasi adalah 4,378.

Distribusi frekuensi data sub variabel perencanaan pembelajaran disajikan pada Tabel 3 berikut ini. 
Tabel 3. Distribusi Frekuensi Data pada Sub Variabel Perencanaan Pembelajaran

\begin{tabular}{cccc}
\hline No & Kelas Interval & $\mathrm{f}$ & $\%$ \\
\hline 1 & $11-13$ & 1 & 2,6 \\
2 & $14-16$ & 4 & 10,5 \\
3 & $17-19$ & 4 & 10,5 \\
4 & $20-22$ & 8 & 21,1 \\
5 & $23-25$ & 11 & 28,9 \\
6 & $26-28$ & 8 & 21,1 \\
7 & $29-31$ & 2 & 5,3 \\
\hline & Jumlah & 38 & 100 \\
\hline
\end{tabular}

Berdasarkan hasil pengumpulan data, terdapat sebanyak terdapat $17 \quad(44,7 \%)$ responden yang memiliki nilai dibawah nilai rata-rata. Sementara itu, $21(55,3 \%)$ responden lainnya memiliki nilai di atas rata-rata. Dengan demikian, data tersebut menunjukkan kurva mendekati normal yaitu skor responden di atas rata-rata memiliki jumlah yang hampir sama dengan skor responden di bawah rata-rata. Kecenderungan data sub variabel perencanaan pembelajaran ditampilkan pada histogram di bawah ini.

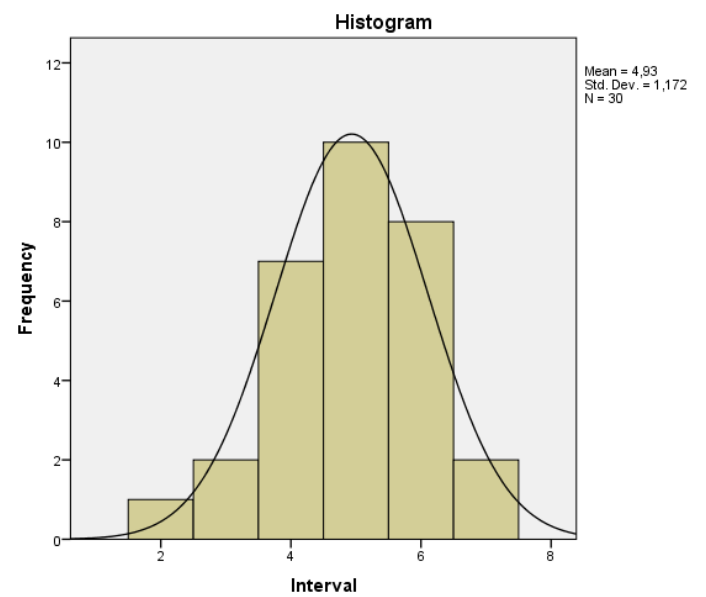

Gambar 1. Histogram Data Sub Variabel Perencanaan Pembelajaran

2. Sub Variabel Pelaksanaan Pembelajaran

Berdasarkan hasil pengolahan data, diperoleh skor terendah pada sub variabel pelaksanaan pembelajaran yaitu 25 sedangkan skor tertingginya diperoleh angka 62. Mean atau rata-rata skor yaitu 46,05 dan median diperoleh angka 48,50. Adapun modusnya berada pada angka 49 sedangkan standar deviasinya yaitu 7,935. Rentang teoritik pada sub variabel pelaksanaan pembelajaran ini adalah 16 hingga 64.

Tabel 4 di bawah ini menyajikan distribusi frekuensi data pada sub variabel pelaksanaan pembelajaran. Tabel tersebut menunjukkan sebanyak 16 responden berada di bawah nilai rata-rata dan sebanyak 22 responden berada di atas nilai rata-rata.

Tabel 4. Distribusi Frekuensi Data pada

Sub Variabel Pelaksanaan Pembelajaran

\begin{tabular}{cccc}
\hline No & Kelas Interval & f & $\%$ \\
\hline 1 & $25-30$ & 1 & 2,6 \\
2 & $31-36$ & 5 & 13,3 \\
3 & $37-42$ & 4 & 10,5 \\
4 & $43-48$ & 9 & 23,7 \\
5 & $49-54$ & 17 & 44,7 \\
6 & $55-60$ & 0 & 0 \\
7 & $61-64$ & 2 & 5,2 \\
\hline & Jumlah & 38 & 100 \\
\hline
\end{tabular}

Data ini menunjukkan data mendekati kurva normal. Kecenderungan data pada sub variabel pelaksanaan pembelajaran dapat dilihat pada histogram berikut ini.

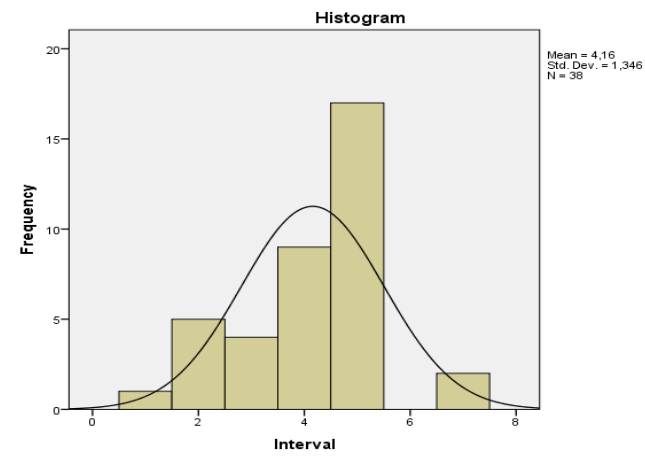

\section{Gambar 2. Histogram Data Sub Variabel Pelaksanaan Pembelajaran}

3. Sub Variabel Penilaian Pembelajaran

Data pada sub variabel penilaian pembelajaran juga menunjukkan kurva normal. Skor terkecil yang diperoleh adalah 16 dan skor tertingginya 37. Rata-rata yang diperoleh dari data pada sub variabel penilaian pembelajaran yaitu 28,37. Sementara itu, mediannya terletak pada angka 29 dan standar deviasinya pada 
angka 5,248. Modus terletak pada angka 29 dan 32. Rentang teoritik pada sub variabel penilaian pembelajaran adalah 10 hingga 40.

Tabel 5. Distribusi Frekuensi Data pada Sub Variabel Pelaksanaan Pembelajaran

\begin{tabular}{cccc}
\hline No & Kelas Interval & $\mathrm{f}$ & $\%$ \\
\hline 1 & $16-18$ & 2 & 5,2 \\
2 & $19-21$ & 3 & 7,9 \\
3 & $22-24$ & 5 & 13,3 \\
4 & $25-27$ & 1 & 2,6 \\
5 & $28-30$ & 9 & 23,7 \\
6 & $31-33$ & 14 & 36,8 \\
7 & $34-37$ & 4 & 10,5 \\
\hline & Jumlah & 38 & 100 \\
\hline
\end{tabular}

Begitu juga dengan distribusi data pada sub variabel penilaian pembelajaran menunjukkan kurva mendekati normal. Sebanyak 14 responden $(36,8 \%)$ memiliki skor di bawah rata-rata dan sebanyak 24 responden $(63,2 \%)$ mencapai skor di atas rata-rata. Distribusi tersebut menunjukkan jumlah sampel yang berada di sisi kiri dan di sisi kanan relatif sama. Kecenderungan distribusi frekuensi pada sub variabel penilaian pembelajaran disajikan pada histogram di bawah ini.

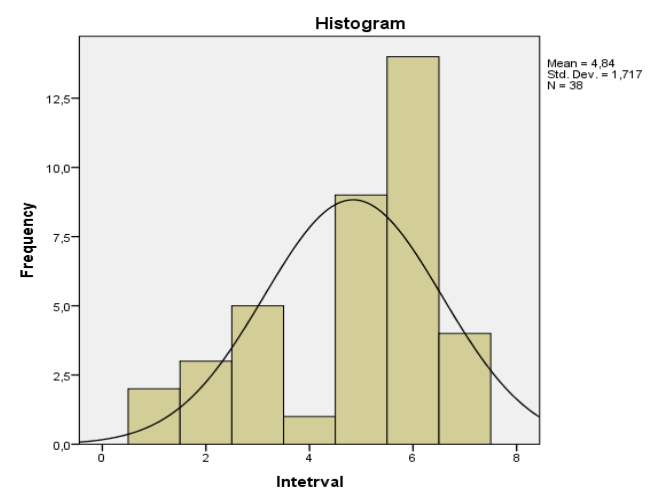

Gambar 3. Histogram Data Sub Variabel Penilaian Pembelajaran

4. Sub Variabel Pengawasan Pembelajaran

Rentang teoritik skor pada sub variabel pengawasan pembelajaran yaitu 8 untuk skor terendah dan 32 untuk skor tertinggi. Berdasarkan hasil pengumpulan data, statistik deskriptif data sub variabel pengawasan pembelajaran menunjukkan skor terendah yaitu 10 dan skor tertinggi yaitu 32. Sementara itu, skor rata-rata pada sub variabel pengawasan pembelajaran diperoleh skor yaitu 23,29. Median terletak pada skor 24 dan modusnya terlihat pada skor 25. Adapun standar deviasinya adalah 4,849 .

Distribusi frekuensi data sub variabel pengawasan pembelajaran disajikan pada Tabel 6 berikut ini.

Tabel 6. Distribusi Frekuensi Data pada Sub Variabel Pengawasan Pembelajaran

\begin{tabular}{cccc}
\hline No & Kelas Interval & f & $\%$ \\
\hline 1 & $10-13$ & 1 & 2,6 \\
2 & $14-17$ & 5 & 13,2 \\
3 & $18-21$ & 4 & 10,5 \\
4 & $22-25$ & 18 & 47,4 \\
5 & $26-29$ & 7 & 18,4 \\
6 & $30-32$ & 3 & 7,9 \\
\hline & Jumlah & 38 & 100 \\
\hline
\end{tabular}

Berdasarkan hasil pengumpulan data, terdapat sebanyak 16 responden $(42,1 \%)$ yang memiliki nilai di bawah nilai rata-rata. Sementara itu, 22 responden lainnya $(57,9 \%)$ memiliki nilai di atas rata-rata. Dengan demikian, data tersebut menunjukkan kurva mendekati normal yaitu skor responden di atas rata-rata memiliki jumlah yang hampir sama dengan skor responden di bawah rata-rata. Kecenderungan data sub variabel pengawasan pembelajaran ditampilkan pada histogram di bawah ini.

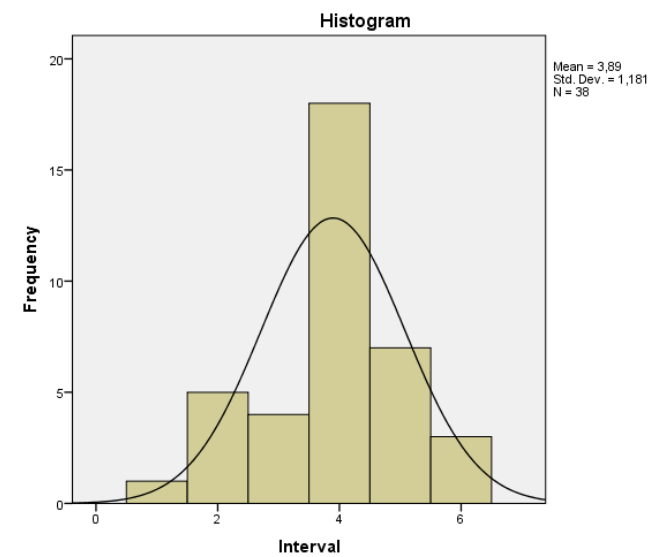

Gambar 4. Histogram Data Sub Variabel Pengawasan Pembelajaran 
Uji validitas instrumen dilakukan terhadap 30 responden sebagai sampel penelitian. Hasil uji validitas instrumen guru dapat dilihat pada Tabel 7 di bawah ini.

Tabel 7. Hasil Uji Validitas Instrumen

\begin{tabular}{cccc}
\hline $\begin{array}{c}\text { Sub } \\
\text { Variabel }\end{array}$ & $\begin{array}{c}\text { Hasil } \\
\text { Valid }\end{array}$ & $\begin{array}{c}\text { Validasi } \\
\text { Tidak } \\
\text { Valid }\end{array}$ & Total \\
\hline $\mathrm{X}_{1}$ & 8 & 0 & 8 \\
$\mathrm{X}_{2}$ & 16 & 0 & 16 \\
$\mathrm{X}_{3}$ & 10 & 0 & 10 \\
$\mathrm{X}_{4}$ & 8 & 0 & 8 \\
\hline Jumlah & 42 & 0 & 42 \\
\hline
\end{tabular}

Tabel 7 menunjukkan bahwa instrumen penelitian terdiri dari 42 pernyataan. Setelah dilakukan uji validasi, tidak ada pernyataan yang dinyatakan tidak valid sehingga semua pernyataan dinyatakan valid yaitu sebanyak 42 pernyataan.

Uji reliabilitas dilakukan terhadap pernyataan-pernyataan yang valid. Hasil perhitungan reliabilitas empat sub variabel penelitian dapat dilihat pada Tabel 8 .

Tabel 8. Hasil Uji Reliabilitas Instrumen

\begin{tabular}{cccc}
\hline $\begin{array}{c}\text { Sub } \\
\text { Variabel }\end{array}$ & $\begin{array}{c}\mathrm{r} \\
\text { hitung }\end{array}$ & $\mathrm{r}$ tabel & Kesimpulan \\
\hline $\mathrm{X}_{1}$ & & 0,6 & Reliabel \\
$\mathrm{X}_{2}$ & & 0,6 & Reliabel \\
$\mathrm{X}_{3}$ & & 0,6 & Reliabel \\
$\mathrm{X}_{4}$ & & 0,6 & Reliabel \\
\hline
\end{tabular}

Berdasarkan perhitungan reliabilitas dengan menggunakan bantuan program Statistical Package for the Social Sciences (SPSS) versi 20 dapat diketahui bahwa keempat sub variabel penelitian memiliki instrumen yang reliabel. Hal ini ditunjukkan dengan nilai $r$ hitung yang lebih besar dari nilai $r$ tabel sebagaimana disajikan pada Tabel 8. Dengan demikian, instrumen penelitian tersebut layak untuk digunakan dalam pengambilan data.

\section{Pembahasan}

Pada dasarnya penelitian ini ingin mendeskripsikan bagaimana implementasi pembelajaran Abad 21 dalam Kurikulum
2013 pada mata palajaran Fisika di SMA Rujukan Provinsi DKI Jakarta. Terdapat empat aspek yang menjadi fokus dalam penelitian ini antara lain perencanaan pembelajaran, pelaksanaan pembelajaran, penilaian pembelajaran dan pengawasan pembelajaran. Berdasarkan hasil/deskripsi data yang telah diuraikan pada sub bagian hasil penelitian, berikut ini disajikan pembahasan dari masing-masing sub variabel penelitian.

1. Perencanaan Pembelajaran Abad 21 dalam Kurikulum 2013

Perencanaan pembelajaran abad 21 dalam Kurikulum 2013 yang dilakukan tampak sudah baik. Hal ini ditunjukkan dari perbandingan skor yang diperoleh dari responden dengan skor teoritisnya. Secara teoritis, skor terendah variabel perencanaan pembelajaran adalah 8 dan skor tertinggi adalah 32. Dengan membagi ke dalam lima rentang skala maka diperoleh skala sebagaimana pada Tabel 9 berikut ini.

Tabel 9. Rentang dan Kategori Skala

Teoritis Sub Variabel Perencanaan

Pembelajaran

\begin{tabular}{cl}
\hline Rentang Nilai & \multicolumn{1}{c}{ Kategori } \\
\hline $8-12$ & Sangat Tidak Baik \\
$13-17$ & Kurang Baik \\
$18-22$ & Cukup Baik \\
$23-27$ & Baik \\
$28-32$ & Sangat Baik \\
\hline
\end{tabular}

Sebagaimana telah disebutkan pada sub bab di atas, skor terendah pada sub variabel perencanaan pembelajaran adalah 13 dan skor tertinggi adalah 31. Berdasarkan Tabel 9, maka dapat diketahui bahwa sebanyak 6 responden $(15,8 \%)$ berada pada kategori kurang baik, 11 responden $(28,9 \%)$ termasuk dalam kategori cukup baik, 17 responden $(44,7 \%)$ termasuk kategori baik dan 4 responden $(10,6 \%)$ termasuk kategori sangat baik. Data ini menunjukkan bahwa perencanaan pembelajaran abad 21 dalam Kurikulum 2013 pada mata pelajaran Fisika di SMA Rujukan Provinsi DKI Jakarta termasuk kategori baik.

Perencanaan pembelajaran abad 21 dalam Kurikulum 2013 meliputi empat 
indikator antara lain ketersediaan silabus, pengembangan Rencana Pelaksanaan Pembelajaran (RPP), prinsip-prinsip penyu-sunan RPP, dan pemilihan bahan ajar atau materi pembelajaran. Keempat hal tersebut sangat berperan penting guna terseleng-garanya pembelajaran yang baik. Dengan perencanaan pembelajaran yang matang, guru dapat lebih mudah dan mempunyai pedoman dalam pelaksanaan pembelajaran. Pembelajaran akan lebih terarah sesuai yang dipersiapkan dalam silabus dan RPP.

\section{Pelaksanaan Pembelajaran Abad 21 dalam Kurikulum 2013}

Hasil analisis data pelaksanaan proses pembelajaran menunjukkan bahwa pelaksanaan proses pembelajaran termasuk ke dalam kategori cukup baik. Hal ini terlihat dari perbandingan skor yang diperoleh responden dengan skor teoritisnya. Skor teoritis terendah pada sub variabel pelaksanaan pembelajaran adalah 16 dan skor tertinggi yaitu 64. Dengan membagi ke dalam lima rentang skala maka diperoleh skala sebagaimana pada Tabel 10 berikut ini.

Tabel 10. Rentang dan Kategori Skala

Teoritis Sub Variabel Pelaksanaan Pembelajaran

\begin{tabular}{cl}
\hline Rentang Nilai & \multicolumn{1}{c}{ Kategori } \\
\hline $16-25$ & Sangat Tidak Baik \\
$26-35$ & Kurang Baik \\
$36-45$ & Cukup Baik \\
$46-55$ & Baik \\
$56-64$ & Sangat Baik \\
\hline
\end{tabular}

Telah diketahui pada pembahasan subbab sebelumnya bahwa skor terendah pada sub variabel pelaksanaan pembelajaran adalah 25 dan skor tertingginya 62. Merujuk pada Tabel 10, maka dapat diketahui sebanyak 1 responden $(2,6 \%)$ berada pada kategori sangat tidak baik, 3 responden $(10,5 \%)$ termasuk kategori kurang baik, 10 responden $(26,3 \%)$ termasuk kategori cukup baik, 21 responden $(55,3 \%)$ pada kategori baik dan 2 responden $(5,2 \%)$ berada pada kategori sangat baik. Jika melihat ketiga ukuran pemusatan data hasil penelitian, maka ketiganya berada pada skala baik. Diketahui bahwa skor rata-rata pelak- sanaan pembelajaran adalah 46,05 , sedangkan nilai mediannya yaitu 48,50 dan nilai modusnya 49. Oleh karena itu ketiga ukuran pemusatan data berada pada skala baik. Data ini menunjukkan bahwa pelaksana-an pembelajaran Abad 21 dalam Kurikulum 2013 pada mata pelajaran Fisika di SMA rujukan provinsi DKI Jakarta masuk dalam kategori baik.

Pelaksanaan pembelajaran abad 21 dalam Kurikulum 2013 meliputi enam indikator antara lain; kegiatan pendahuluan pembelajaran; pengelolaan kegiatan inti dan penguasaan materi pelajaran; pemanfaatan sumber dan media/alat pembelajaran; penguatan keterampilan Abad 21 (Communication, Collaboration, Critical Thinking, \& Creativity / 4C); kegiatan penutupan pembelajaran.

3. Penilaian Pembelajaran Abad 21 dalam Kurikulum 2013

Perbandingan skor yang diperoleh dari responden dengan skor teoritis, terlihat bahwa penilaian pembelajaran abad 21 dalam Kurikulum 2013 sudah baik. Skor teoritis terendah pada sub variabel penilaian pembelajaran yaitu 10, adapun skor tertingginya adalah 40. Dengan membagi ke dalam lima rentang skala maka diperoleh skala sebagaimana pada Tabel 11 berikut ini.

Tabel 11. Rentang dan Kategori Skala Teoritis Sub Variabel Penilaian Pembelajaran

\begin{tabular}{cl}
\hline Rentang Nilai & \multicolumn{1}{c}{ Kategori } \\
\hline $10-15$ & Sangat Tidak Baik \\
$16-21$ & Kurang Baik \\
$22-28$ & Cukup Baik \\
$29-34$ & Baik \\
$35-40$ & Sangat Baik \\
\hline
\end{tabular}

Berdasarkan Tabel 11, sebanyak 5 responden $(13,2 \%)$ berada pada kategori kurang baik, 9 responden $(23,7 \%)$ berada pada kategori cukup baik, 22 responden $(57,9 \%)$ pada kategori baik dan 2 responden $(5,2 \%)$ termasuk kategori sangat baik. Dengan demikian, penilaian pembelajaran abad 21 dalam Kurikulum 2013 dapat dikatakan baik. 
Sama halnya dengan hasil dari tiga pemusatan data yang menunjukkan skala yang sama. Skor rata-rata yaitu 28,37 , median 29 dan modusnya yaitu 29 dan 32. Jika dilihat pada Tabel 7 , maka ketiga nilai pemusatan data berada pada skala baik. Hal ini menunjukkan bahwa penilaian pembe-lajaran abad 21 dalam Kurikulum 2013 sudah baik.

Terdapat lima indikator dalam sub variabel penilaian pembelajaran abad 21 dalam Kurikulum 2013 antara lain; perancangan penilaian; prinsip penilaian; pelaksanaan evaluasi belajar; pelaporan hasil belajar; dan instrumen penilaian.

4. Pengawasan Pembelajaran Abad 21 dalam Kurikulum 2013

Pengawasan pembelajaran abad 21 dalam Kurikulum 2013 yang dilakukan tampak sudah baik. Hal ini ditunjukkan dari perbandingan skor yang diperoleh dari responden dengan skor teoritisnya. Secara teoritis, skor terendah variabel perencanaan pembelajaran adalah 8 dan skor tertinggi adalah 32. Dengan membagi ke dalam lima rentang skala maka diperoleh skala sebagaimana pada Tabel 12.

Sebagaimana telah disebutkan pada sub bab di atas, skor terendah pada sub variabel pengawasan pembelajaran adalah 10 dan skor tertinggi adalah 32. Berdasarkan Tabel 12, maka dapat diketahui bahwa sebanyak satu responden $(2,6 \%)$ berada pada kategori sangat tidak baik, 5 responden $(13,2 \%)$ termasuk dalam kategori kurang baik, 8 responden $(21,1 \%)$ kategori cukup baik, 16 responden $(42,1 \%)$ dalam kategori baik dan 8 responden $(21,1 \%)$ pada kategori sangat baik. Data ini menunjukkan bahwa pengawasan pembelajaran abad 21 dalam Kurikulum 2013 pada mata pelajaran Fisika di SMA Rujukan Provinsi DKI Jakarta termasuk kategori baik.

Tabel 12. Rentang dan Kategori Skala

Teoritis Sub Variabel Pengawasan Pembelajaran

\begin{tabular}{cl}
\hline Rentang Nilai & \multicolumn{1}{c}{ Kategori } \\
\hline $8-12$ & Sangat Tidak Baik \\
$13-17$ & Kurang Baik \\
$18-22$ & Cukup Baik \\
$23-27$ & Baik \\
$28-32$ & Sangat Baik \\
\hline
\end{tabular}

Pengawasan pembelajaran abad 21 dalam Kurikulum 2013 khususnya dari sisi guru meliputi dua indikator antara lain; prinsip pengawasan; pelaksanaan supervisi; dan tindak lanjut.

\section{PENUTUP}

Berdasarkan hasil dan pembahasan penelitian, maka dapat disimpulkan beberapa poin sebagai berikut. Perencanaan pembelajaran abad 21 dalam Kurikulum 2013 pada mata pelajaran Fisika di SMA Rujukan provinsi DKI Jakarta sudah baik. Begitu pula dengan pelaksanaan pembelajaran abad 21 dalam Kurikulum 2013 pada mata pelajaran Fisika di SMA Rujukan provinsi DKI Jakarta juga masuk dalam kategori baik. Selanjutnya, penilaian pembelajaran abad 21 dalam Kurikulum 2013 pada mata pelajaran Fisika di SMA Rujukan provinsi DKI Jakarta sudah terbukti baik. Kemudian variabel pengawasan pembe-lajaran abad 21 dalam Kurikulum 2013 pada mata pelajaran Fisika di SMA Rujukan provinsi DKI Jakarta juga sudah baik.

Rekomendasi untuk penelitian sejenis yang mungkin akan dilakukan antara lain: Metode penelitian dapat menggunakan mixed method agar dapat menggali informasi yang lebih mendalam. Contohnya seperti alasan guru lebih sering menggunakan media Power Point dibandingkan dengan media pembelajaran lainnya. Penggunaan mixed method juga bertujuan agar dapat mengurangi kelemahan pada penelitian kuantitatif. Kedua, responden penelitian dapat melibatkan unsur-unsur selain guru yang secara langsung bersentuhan dengan pembelajaran. Contohnya seperti peserta didik, kepala sekolah, dan pengawas. Dengan begitu, informasi yang didapatkan tidak hanya dari satu jenis sumber sehingga dapat memperluas temuan penelitian.

\section{UCAPAN TERIMA KASIH}

Penulis mengucapkan terima kasih khususnya kepada Bapak Dr. Rusman, M.Pd selaku dosen pembimbing yang telah memberikan banyak masukan dan arahan 
sehingga penelitian ini dapat selesai tepat waktu.

\section{DAFTAR PUSTAKA}

Clorawati, A.R., Rohiyat, S., \& Amir, H. (2017). Implementasi kurikulum 2013 bagi guru kimia di SMA negeri sekota Bengkulu. Jurnal Pendidikan Ilmu Kimia. Vol. 1(2). Hlm. 132-135.

Fitriyah, A. \& Arief, A. (2017). Penerapan model pembelajaran kooperatif tipe TAI (Team Assisted Individualization) untuk meningkatkan aktivitas dan hasil belajar siswa kelas x pada pokok bahasan momentum dan impuls di MAN Mojosari Mojokerto. Jurnal Inovasi Pendidikan Fisika. Vol. 6(3). pp. 153-156.

Istyowati, A., Kusairi, S., \& Handayanto, S.K. (2017). Analisis pembelajaran dan kesulitan siswa SMA kelas xi terhadap penguasaan konsep Fisika. Prosiding Seminar Nasional III Biologi, Pembelajaran, dan Lingkungan Hidup Perspektif Interdisipliner. pp. 237-243, Malang: Universitas Muhammadiyah Malang.

Kamiludin, K. \& Suryaman, M. (2017). Problematika pada pelaksanaan penilaian pembelajaran kurikulum 2013. Jurnal Prima Edukasia. Vol. 5(1). Hlm.58-67.

Kemendikbud. (2013). Kurikulum 2013 SD - panduan teknis penilaian sekolah dasar. Jakarta: Dit. PSMP Kemendikbud.

Lestari, R., Ahdinirwanto, W., \& Ashari. (2013). Peningkatan pemecahan masalah melalui model pembelajaran cooperative integrated reading and composition (CIRC) pada SMP Negeri 4 Wadaslintang. Jurnal Radiasi, 4(2): 178-181.

Miller, L. C., \& Northern, T. (2011). 21st Century skills: prepare student for the future. Kappa Delta Pi Record. 121123.

Murti, K. E. (2015). Pendidikan abad 21 dan aplikasinya dalam pembelajaran di SMK. Tersedia secara online di: http://p4tksb-

jogja.com/arsip/images/Pendidikan\% 20Abad\%2021 [diakses di Jakarta, Indonesia: 4 Januari 2018].

Nursamsu dan Baihaqi. (2016). Implementasi kurikulum 2013 bagi guru SMA negeri Aceh Tamiang. Jurnal Pendidikan Biologi. Vol. 5(3). Hlm. 193-199.

Sudarsana, I.K. (2018). Pengaruh model pembelajaran kooperatif terhadap peningkatan mutu hasil belajar siswa. Jurnal Penjaminan Mutu, Lembaga Penjaminan Mutu, Institut Hindu Dharma Negeri Denpasar. Vol. 4(1), pp. 20-31.

Sufairoh. (2016). Pendekatan saintifik \& model pembelajaran K-13. Jurnal Pendidikan Profesional. Vol. 5(3). Hlm. 116-125.

Sugiyono. (2013). Metodologi penelitian kuantitatif, kualitatif dan $R \& D$. Bandung: Alfabeta.

Susilana, R. \& Rusman. (2015). Implementasi kurikulum 2013 di sekolah dasar. Edutech. Vol. 1(1), pp. 52-67.

Wahyudin, D., Rusman, \& Rahmawati, Y. (2017). Penguatan life skills dalam implementasi kurikulum 2013 pada SMA (sekolah menengah atas) di Jawa Barat. Mimbar Pendidikan: Jurnal Indonesia untuk Kajian Pendidikan. Vol. 2(1) Maret, hlm.6580.

Parasamya, C.E., dan Wahyuni, A. (2017). Upaya peningkatan hasil belajar fisika siswa melalui penerapan model pembelajaran problem based learning (PBL). Jurnal Ilmiah Mahasiswa (JIM) Pendidikan Fisika. Vol. 2(1), pp. 42-49. 